\title{
Shrimps from the Santana Group (Cretaceous: Albian): new species (Crustacea: Decapoda: Dendrobranchiata) and new record (Crustacea: Decapoda: Caridea)
}

\author{
ALLYSSON P. PINHEIRO $^{1}$, ANTÔNIO ÁF. SARAIVA ${ }^{1}$ and WILLIAM SANTANA ${ }^{2}$ \\ ${ }^{1}$ Departamento de Ciências Físicas e Biológicas, Universidade Regional do Cariri/ URCA, \\ Rua Cel. Antônio Luis, 1161, Pimenta, 63100-000 Crato CE, Brasil \\ ${ }^{2}$ Pró-Reitoria de Pesquisa e Pós-Graduação, Universidade Sagrado Coração/ USC, \\ Rua Irmã Arminda, 10-50, Jd. Brasil, 17011-160 Bauru, SP, Brasil \\ Manuscript received on August 20, 2013; accepted for publication on November 26, 2013
}

\begin{abstract}
The fossil shrimp Araripenaeus timidus n. gen. n. sp. is the first fossil Penaeoidea from Brazil. Here, we describe, illustrate and compare it with Paleomattea deliciosa, a fossil Sergestoidea (Dendrobranchiata) previously described from the same region. The material of the early Cretaceous (Albian) was collected in the town of Jardim, south of the state of Ceará, in the superior septarian concretion level of the Romualdo Formation. Additionally, a second specimen of Kellnerius jamacaruensis was found in the same site of the Araripe Basin.
\end{abstract}

Key words: Romualdo Formation, fossil Penaeoidea, Araripe Basin, Carbonatic concretions, Araripenaeus timidus.

\section{INTRODUCTION}

The superfamily Penaeoidea Rafinesque, 1815 is a very important group commercially, including several species fished in large scale in tropical and subtropical seas of the world (Pérez Farfante and Kensley 1997). This group is represented by approximately 430 recent and 96 fossil species (De Grave et al. 2009). The fossil record of penaeoids extends back to the Devonian, representing, along with the macruran Palaeopalaemon newberryi Whitfield, 1880, the oldest known shrimps (Schram et al. 1978, 2000, Feldmann and Schweitzer 2010). Despite being very old in the fossil record, shrimps are in general poorly preserved, lacking most of its diagnostic characters (Garassino and Bravi

Correspondence to: William Santana

E-mail: william_santana@yahoo.com.br
2003, Feldmann and Schweitzer 2010, Santana et al. 2013). The only dendrobranchiate known from Brazil is a sergestoid shrimp, Paleomattea deliciosa Maisey and Carvalho, 1995 found in the Araripe Basin, in the state of Ceará (Viana and Agostinho 1995, Martins-Neto 2005).

The Araripe Basin is a very important paleontologic region, well-known for its numerous important fossil findings. In this area the rich fossil biota forms a palaeoenvironment with numerous known species of plants (Lima et al. 2012), invertebrates (mostly arthropods), and vertebrates (Maisey 1991). Among arthropods, three shrimps, the palaemonids (Caridea) Beurlenia araripensis Martins-Neto and Mezzalira, 1991, Kellnerius jamacaruensis Santana, Pinheiro, Silva and Saraiva, 2013 and the sergestid Paleomattea deliciosa are 
found within two formations, the Crato and the Romualdo. In the Araripe Basin, the Romualdo and Crato formations (sensu Neumann and Cabrera 1999) of the Santana Group are the most documented lithostratigraphic units because of the excellent preservation of the fossils found in their layers (Kellner 2002, Viana and Neumann 2002).

In this study, we describe a new genus and species of a fossil Penaeoidea, compare it with the other known dendrobranchiate fossil found in Brazil, and establish a new record for the Kellnerius jamacaruensis (Caridea) in the Araripe Basin. Abbreviations are as follows: million years (myr); Museu de Ciências Naturais e de História Barra do Jardim (MCNHBJ).

\section{GeOLOGICAL SETtING}

The Santana Group (sin-rift phase of the Araripe Basin) is a Cretaceous sedimentary unit deposited during the opening of the South Atlantic Ocean, and is associated with lacustrine and transitional marine sediments (Valença et al. 2003, Fara et al. 2005). Since the first fossil discoveries, several authors have presented different interpretations for the stratigraphy of the region (Small 1913, Ponte and Appi 1990, Martill and Wilby 1993, Neumann and Cabrera 1999, Martill 2007). The temporal range of the basin is also controversial. Some investigators estimate the shales to be Aptian (Brito 1984, Wellnhofer 1985, 1991), while others consider them to be Aptian-Albian (Arai et al. 2000), Albian (Campos and Wenz 1982, Berthou 1990), or possibly Turonian (Beurlen 1962). The temporal range variation estimated for the Santana Group is $30 \mathrm{myr}$ (see Kellner et al. 2013 for a review), which makes a precise dating very controversial, and imposes a time chart to be followed to identify each fossil find. In this study, we followed the stratigraphy proposed by Valença et al. (2003) regarding the time and nomenclatural questions about the basin, especially to the stratigraphic units of the Santana Group, where the fossiliferous assemblage of Romualdo
Formation is located. These authors considered this fossiliferous assemblage to have its sediments related to the Albian stage.

The Romualdo Formation is composed of interbedded shales, marls, and limestones with abundant concretions containing fossils (Valença et al. 2003), especially fish and reptile bones (Price 1959, Maisey 1991, Riff et al. 2010), turtles (Hirayama 1998, Oliveira and Romano 2007, Romano et al. 2013), pterosaurs (e.g. Kellner and Campos 2000, 2002, Kellner and Tomida 2000, Vila-Nova and Sayão 2012, Kellner 2013, Kellner et al. 2013) and a few dinosaurs (e.g. Kellner and Campos 2000), several invertebrate microfossils (Coimbra et al. 2002), gymnosperms, and some angiosperms (Carvalho and Santos 2005), as well as the occurrence of amber (Valença et al. 2003). The lower section of these limestones provides evidence of a short marine transgression. Later in the Albian, the area experienced a more important and somewhat longer-lasting marine invasion, recorded by marine deposits. This sequence is interpreted as a gulf cycle lake, part of a system caused by the separation of South America from Africa (Valença et al. 2003).

The material was collected in the town of Jardim, south of the state of Ceará (Figure 1), in a civil construction site. The fossil imprint of the new species was found in a concretion on the superior septarian level, which is characterized by the presence of dark shales surrounding carbonatic concretions that have an internal cavity lined with calcite crystals (Figure 2). A new specimen of Kellnerius jamacaruensis (Figure 3) was found at the same concretion.

\section{SYSTEMATIC PALAEONTOLOGY}

Order Decapoda Latreille, 1802

Remarks: According to Brooks (1962), the archetype of the Eumalacostraca Grobben, 1892 should have a carapace, and within this group 


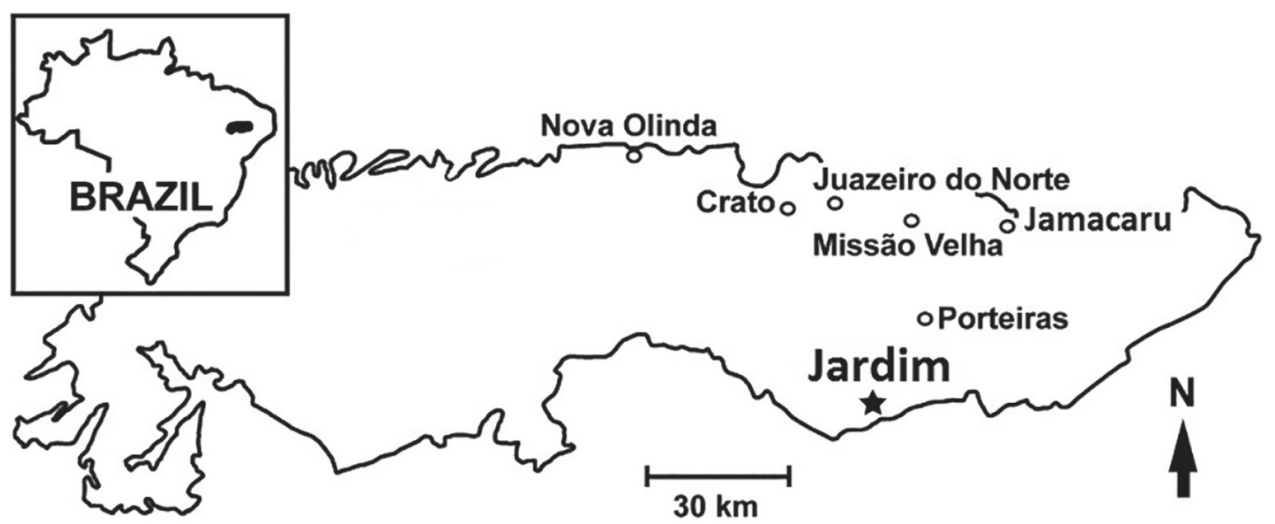

Figure 1 - Geographic position of the sampling site in the town of Jardim, Araripe Basin, south of the state of Ceará, northeast Brazil.

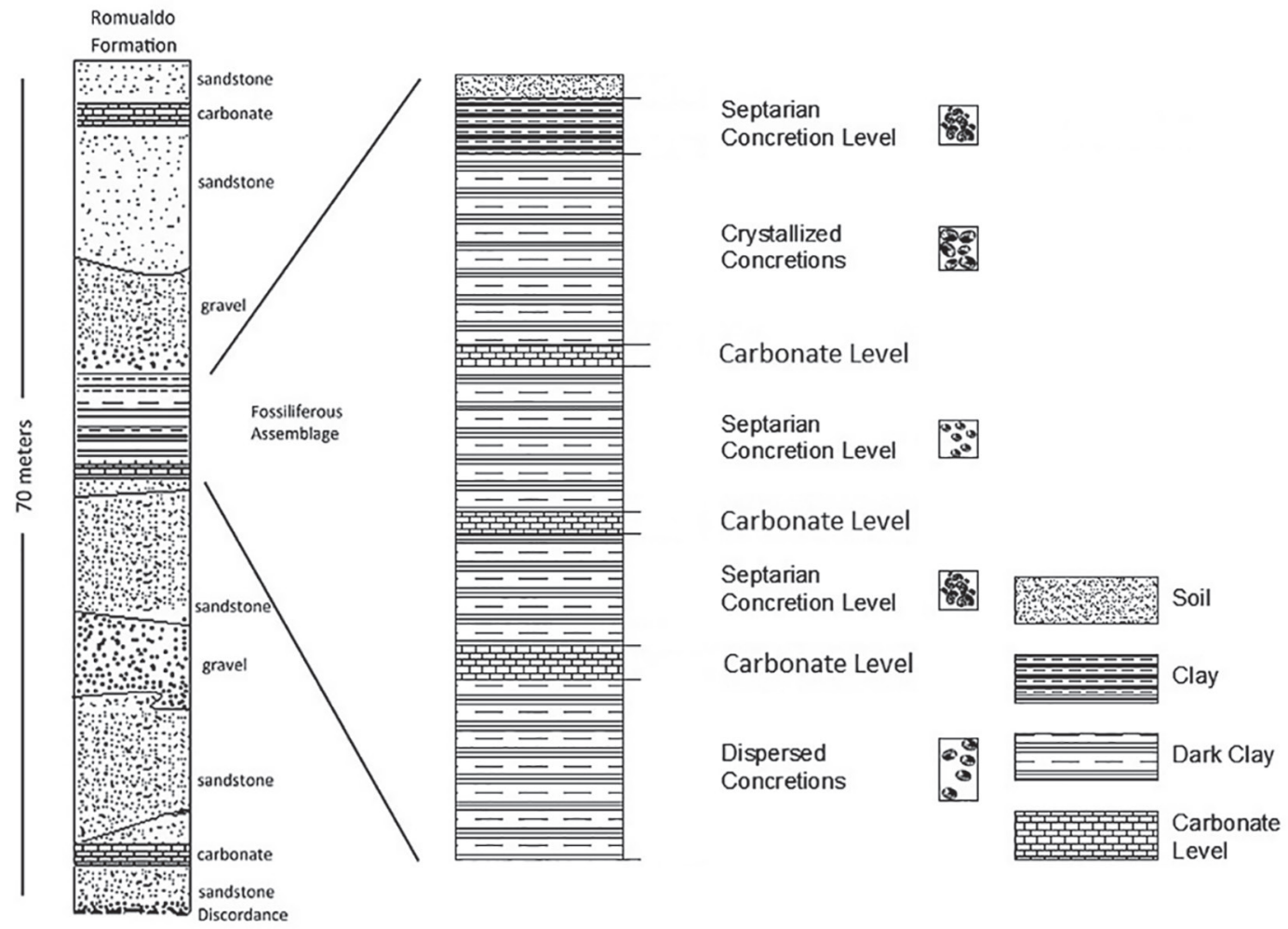

Figure 2 - Stratigraphic general scheme of the Romualdo Formation (Cretaceous - Albian). The details of the fossiliferous assemblage are hypothesized from correlated areas (according to Vila-Nova et al. 2011).

several species are shrimplike in appearance (Feldmann and Schweitzer 2010). The presence of a carapace was also used by Latreille (1802: 341) on the designation of the taxa belonging to Decapoda. The placement of the new species into Decapoda was based on the carapace covering the thorax, although the anterior half of the carapace was not preserved; the posterior margin of the carapace partially covering the first abdominal somite; and the presence of six well developed abdominal somites. Other diagnostic characters of decapods could not be observed due to the 


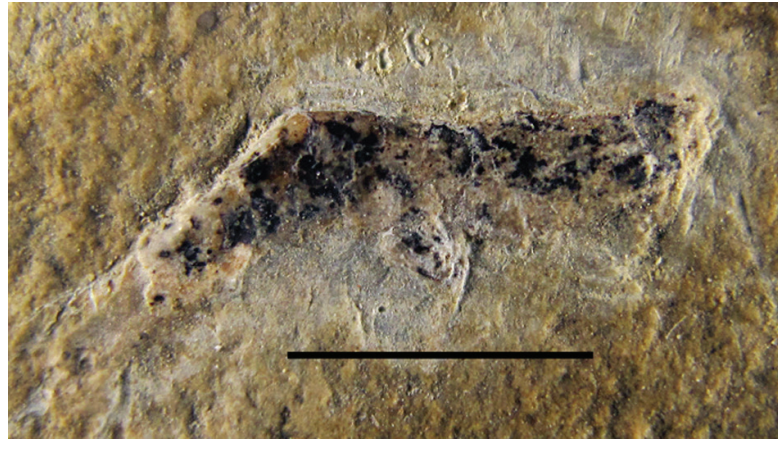

Figure 3 - Lateral view of Kellnerius jamacaruensis (MCNHBJ 339) from Romualdo Formation, Araripe Basin, Brazil. Scale bar: $5 \mathrm{~mm}$.

limited preservation of the material. However, with the characters presented, it is clear to us that this species belongs to the order Decapoda.

Suborder Dendrobranchiata Bate, 1888

Superfamily Penaeoidea Rafinesque, 1815

Remarks: Penaeoidea shrimps have some distinct features, such as the lateral compression of the carapace, and the form and disposal of the pleuras in the abdominal somites. Differently from the Caridea, in which the pleura of the second abdominal somite overlap the first and the third, in Penaeoidea the pleuras of the anterior somites always overlap the posterior somites (Glaessner 1969, Feldmann and Schweitzer 2010). According to several authors, this character is one of the diagnostic characters for Dendrobranchiata (Burkenroad 1981, Pérez Farfante and Kensley 1997, Dixon et al. 2003, Tavares and Martin 2010). We believe this new species belongs to the superfamily Penaeoidea due to the proportion of the sixth abdominal somite, which is considerably more elongated in several sergestid species, including Paleomattea deliciosa, described from the same formation (Maisey and Carvalho 1995). Other diagnostic features of Penaeoidea were not preserved in this specimen.

Family Incertae sedis

Araripenaeus n. gen.
Type species: Araripenaeus timidus n. sp. by present designation.

Etymology: The name Araripenaeus is a combination of Araripe, the basin where the material was collected, and the generic name Penaeus, commonly associated with several penaeoid genera. Gender masculine.

Diagnosis: Abdomen laterally compressed, six segmented, all somites without spines; sixth somite with a sinuous cicatrix. Second to fifth somites are about the same length, the sixth being twice as long as the others somites.

\section{Araripenaeus timidus n. sp.}

Figure 4A-B

Type material: MCNHBJ 339, holotype.

Type locality: Jardim municipality, south of the state of Ceará.

Stratigraphic unit: Romualdo Formation, Santana Group, Araripe Basin.

Age: Early Cretaceous - Albian.

Etymology: From the Latin adjective timidus (nominative, masculine), shy, timid, alluding to the lack of preservation of the anterior region of the cephalothorax.

Diagnosis: The same as for the genus.

Description: fossil in lateral view. Total length of $16.66 \mathrm{~mm}$, without telson; carapace partially preserved with $3.61 \mathrm{~mm}$ long and $3.4 \mathrm{~mm}$ high; abdomen $13.05 \mathrm{~mm}$ long. Anterior region of the carapace not preserved, laterally compressed, ventral margin smooth; dorsal margin of carapace slightly curved, posterior margin rounded ventrally, both margins without spines; no sign of ornamentation. Rostrum, eye stalks, antennules, antenna and third maxilliped not preserved. Only coxa of the first to fifth pereiopods preserved, without ornamentation. Abdomen laterally compressed, six segmented, all 

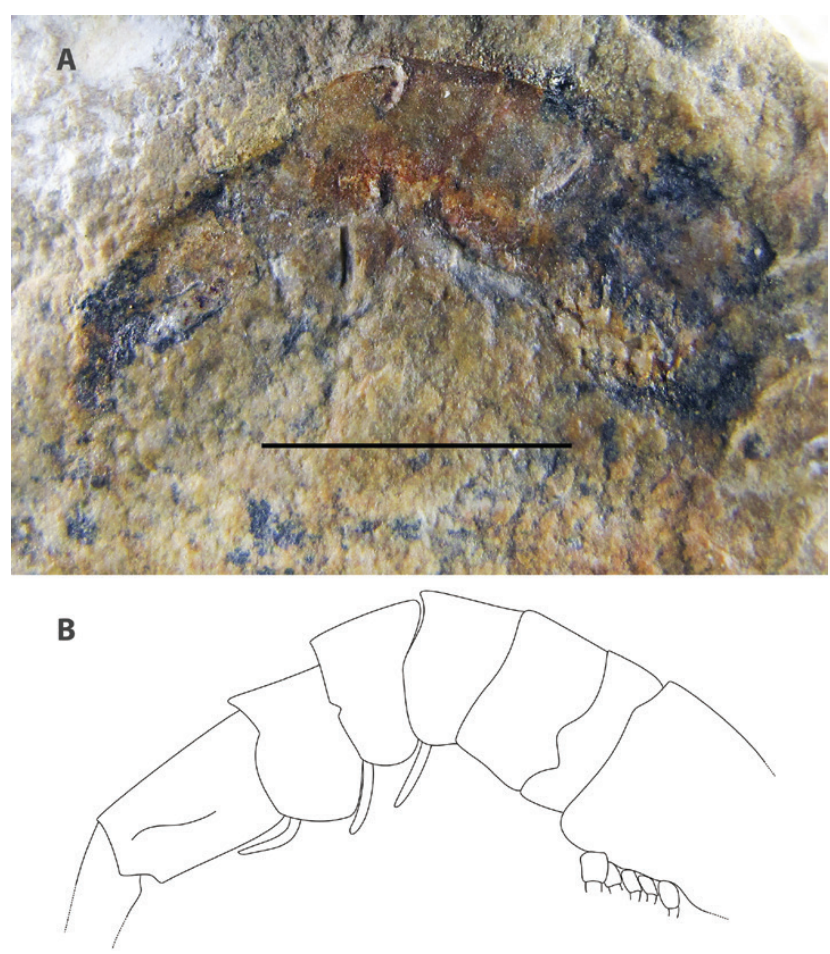

Figure 4 - Araripenaeus timidus n. gen. n. sp. (MCNHBJ 339). A, lateral view of the holotype. B, line drawing of the holotype. Scale bar: $5 \mathrm{~mm}$.

somites apparently without spines; sixth somite with a sinuous cicatrix. Second pleura not overlapping the first; first to third pleura with slightly curved ventral margin; well-developed pleura on the fourth and fifth somites, with a roughly triangular ventral margin. First segment apparently compressed giving the impression of a sinuous posterior margin. Second to fifth somites about the same length, sixth twice as long as the other somites; hinge joint evident only in fifth and sixth somites. Pleopods on first and second somites not preserved, third to fifth poorly laterally preserved; segmentation and differentiation between endopod and exopod not visible. Only a small proximal fragment of uropods and telson faintly preserved.

Remarks: Several specimens of shrimplike decapods are found in the Santana Group of the Araripe Basin (Beurlen 1963, Martins-Neto and Mezzalira 1991, Maisey and Carvalho 1995, Saraiva et al.
2009, Santana et al. 2013). In this context, we have three species, the carideans Beurlenia araripensis Martins-Neto and Mezzalira, 1991, Kellnerius jamacaruensis Santana, Pinheiro, Silva and Saraiva, 2013, and the sergestid Paleomattea deliciosa Maisey and Carvalho, 1995. The carideans are considered to be rare in the fossil record (Garassino and Bravi 2003); however, they are more frequently found in Brazil than the dendrobranchiate shrimps (Martins-Neto 2005). Araripenaeus timidus n. gen. n. sp. is the second Dendrobranchiata and the first penaeoid shrimp described from Brazil. Despite the few features preserved in the material described here, we believe Araripenaeus timidus n. gen. n. sp. to be a dendrobranchiate shrimp (see above), thus comparisons are made only with Paleomattea deliciosa. Two characters differentiate Araripenaeus timidus n. gen. n. sp. from P. deliciosa: (i) the presence of a marked sinuous cicatrix in the sixth abdominal somite (absent in P. deliciosa); (ii) and the sixth 
abdominal somite being two times longer than the anterior somites (three times longer in P. deliciosa). Despite the few characters available for Araripenaeus timidus n. gen. n. sp., we believe these features clearly differentiate the new species from $P$. deliciosa. The presence of sergestoid and penaeoid shrimps in the same area is expected due to the environmental characteristics as observed in the recent species of these superfamilies.

In the same concretion where Araripenaeus timidus n. gen. n. sp. was found, a second specimen of Kellnerius jamacaruensis (MCNHBJ 339) was collected (Figure 3). The identification of this material was based on the presence of a distinct groove on the third abdominal somite not extending to the pleurite (Santana et al. 2013). This represents new material of $K$. jamacaruensis and confirms the importance of the diagnostic characters established for this species.

The sympatric occurrence of extant dendrobranchiate and carideans in estuarine and/or marine environments is very common. The great majority of dendrobranchiate shrimps, at least in some part of their life cycle, live in marine and/or estuarine waters, with only a few exceptions of sergestids which are exclusively found in freshwater (Pérez Farfante and Kensley 1997, Tavares and Martin 2010). This environmental condition is the same described for the area where A. timidus n. gen. n. sp. and K. jamacaruensis were found. Additionally, we believe that both species are from shallow water. Typical shallow water estuarine and/or marine fossil fishes, as Vinctifer comptoni (Agassiz, 1841), Tharrhias araripis Jordan and Branner, 1908 and Branneriun latum (Agassiz, 1841), are commonly found in concretions at the same levels where $A$. timidus n. gen. n. sp. and $K$. jamacaruensis were found (Saraiva et al. 2007). Also, at this level of the Romualdo Formation, exclusively marine groups (e.g. Echinodermata) are not found. These groups are normally found $20 \mathrm{~m}$ above this fossiliferous assemblage. Therefore, the species found, support the evidences of a paleoenvironment with marine transgressions or transitional marine areas such as estuarine environments.

\section{ACKNOWLEDGMENTS}

We thank Fundação Cearense de Apoio ao Desenvolvimento Científico e Tecnológico (FUNCAP) and Conselho Nacional de Desenvolvimento Científico e Tecnológico (CNPq) for the financial support. We are in debt to Dion Saraiva for the help with the stratigraphic scheme, and José Coutinho Junior from the Museu de Ciências Naturais e de História Barra do Jardim (MCNHBJ) for the loan of the material. WS thanks the Universidade Sagrado Coração (USC) for supporting studies on the systematics of decapod crustaceans.

\section{RESUMO}

O camarão fóssil Araripenaeus timidus n. gen. n. sp. é o primeiro Penaeoidea fóssil descrito para o Brasil. No presente trabalho ele é descrito, ilustrado e comparado com Paleomattea deliciosa, um Sergestoidea fóssil (Dendrobranchiata), previamente descrito para a mesma região. O material do Cretáceo inferior (Albiano) foi coletado na cidade Jardim, sul do estado do Ceará, no nível superior das concreções septárias da Formação Romualdo. Adicionalmente, um segundo espécimen de Kellnerius jamacaruensis é registrado para a mesma localidade na Bacia do Araripe.

Palavras-chave: Formação Romualdo, Penaeoidea fóssil, Bacia do Araripe, Concreções carbonáticas, Araripenaeus timidus.

\section{REFERENCES}

AgASSIZ L. 1833-44. Recherches sur les Poissons Fossiles. 5 volumes and Atlas. Neuchatel: Imprimerie Petitpierre, $1420 \mathrm{p}$.

Arai M, Neto JB, Lana CC And Pedrao E. 2000. Cretaceous dinoflagellate provincialism in Brazilian marginal basins. Cretaceous Res 21: 351-366.

BERTHOU PY. 1990. Le bassin d'Araripe et les petits bassins intracontinentaux voisins (N.E. du Brésil); formation et evolution dans le cadre de l'ouverture de l'Atlantic Equatorial - comparaison avec lês bassins Ouest-Africains situés dans lê même contexte. Simpósio sobre a Bacia do Araripe e Bacias Interiores do Nordeste, p. 113-134.

BeURLEN K. 1962. A Geologia da Chapada do Araripe. An Acad Bras Cienc 34: 365-370. 
BeuRLEN K. 1963. Geologia e estratigrafia da Chapada do Araripe. XVII Congresso Brasileiro de Geologia. SUDENE (ed) Rio de Janeiro, p. 1-47.

BRITO IM. 1984. The upper Lower Cretaceous in Brazil, its divisions and boundaries. An Acad Bras Cienc 56: 287-293.

BRoOKS HK. 1962. Devonian Eumalacostraca. Arkiv för Zoologi, Uppsala 15: 307-315.

BURKENROAD MD. 1981. The higher taxonomy and evolution of Decapoda (Crustacea). Trans San Diego Soc Nat Hist 19: 251-268.

Campos DA And Wenz S. 1982. Premiére découverte de Coelacanthes dans le Crétacé inférieur de la Chapada do Araripe (Brésil). CR Acad Sci II A 294: 1151-1154.

CARVAlHo MSS AND SANTOS MECM. 2005. Histórico das Pesquisas Paleontológicas na Bacia do Araripe, Nordeste do Brasil. Anu Inst Geocienc 28: 15-34.

COIMBRA JC, ARAI M AND CARRENO AL. 2002. Biostratigraphy of Lower Cretaceous microfossils from the Araripe Basin, northeastern Brazil. Geobios 35: 687-698.

DE GRAVE S ET AL. 2009. A classification of living and fossil genera of decapod crustaceans. Raffles Bull Zoo Supplement No. 21, p. 1-109.

Dixon CJ, Ahyong ST AND Schram FR. 2003. A new hypothesis of decapod phylogeny. Crustaceana 76: 935-975.

FARA E, SARAIVA AAF, CAMPOS DDA, MOREIRA JKR, SIEBRA DC AND KELLNER AWA. 2005. Controlled excavations in the Romualdo Member of the Santana Formation (Early Cretaceous, Araripe Basin, northeastern Brazil): stratigraphic, palaeoenvironmental and palaeoecological implications. Palaeogeogr Palaeoclimatol Palaeoecol 218: $145-160$.

FELDMANn RMAnd SCHWEITZER CE. 2010. The Oldest Shrimp (Devonian: Famennian) and Remarkable Preservation of Soft Tissue. J Crustacean Biol 30: 629-635.

GARAssino A AND Bravi S. 2003. Palaemon antonellae new species (Crustacea, Decapoda, Caridea) from the Lower Cretaceous "Platydolomite" of Profeti (Caserta, Italy). J Paleontol 77: 589-592.

Glaessner MF. 1969. Decapoda. In: MOORE RC (Ed), Part R Arthropoda 4(2). The University of Kansas Press and The Geological Society of America, Lawrence, Kansas, p. R399-R533, p. R626-R628.

HIRAYAMA R. 1998. Oldest known sea turtle. Nature 392: 705-708.

JORDAN DS AND BRANNER JC. 1908. The Cretaceous Fishes of Ceará, Brazil. Smithson Inst Misc Collec, LII, p. 1-29.

Kellner AWA. 2002. Membro Romualdo da Formação Santana, Chapada do Araripe, CE - Um dos mais importantes depósitos fossilíferos do Cretáceo brasileiro. In: SCHOBBENHAUS C et al. (Eds), Sítios Geológicos e Paleontológicos do Brasil. DNPM/CPRM - Comissão Brasileira de Sítios Geológicos e Paleobiológicos (SIGEP), Brasília, p. 121-130.

KeLlner AWA. 2013. A new unusual tapejarid (Pterosauria, Pterodactyloidea) from the Early Cretaceous Romualdo Formation, Araripe Basin, Brazil. Earth Environ Sci Trans R Soc Edinburgh 103: 1-13.
Kellner AWA AND CAMPos DA. 2000. Brief review of dinosaur studies and perspectives in Brazil. An Acad Bras Cienc 72: 509-538.

Kellner AWA And Campos DA. 2002. The Function of the Cranial Crest and Jaws of a Unique Pterosaur from the Early Cretaceous of Brazil. Science 297: 389-392.

KELLNER AWA ET AL. 2013. The largest flying reptile from Gondwana: a new specimen of Tropeognathus cf. T. mesembrinus Wellnhofer, 1987 (Pterodactyloidea, Anhangueridae) and other large pterosaurs from the Romualdo Formation, Lower Cretaceous, Brazil. An Acad Bras Cienc 85: 113-135.

Kellner AWA AND TOMIDA Y. 2000. Description of a new species of Anhangueridae (Pterodactyloidea) with comments on the pterosaur fauna from the Santana Formation (Aptian-Albian), northeastern Brazil. Natl Sci Mus Monogr 17: ix-x, 1-135.

LATREILLE PA. 1802. Histoire naturelle, générale et particulière des Crustacés et des Insectes. Ouvrage faisant suite à l'histoire naturelle générale et particulière, composée par Leclerc de Buffon, et rédigée par C.S. Sonnini, membre de plusieurs sociétés savantes. Familles naturelles des genres. (3). Paris: F. DuFart.

LIMA FJ, SARAIVA AAF AND SAỸ̃o JM. 2012. Revisão da Paleoflora das Formações Missão Velha, Crato e Romualdo, Bacia do Araripe, Nordeste do Brasil. Estudos Geológicos 22: 99-115.

MAISEY JG. 1991. Santana Fossils: An Illustrated Atlas. New Jersey: T.F.H. Publications, Neptune City 459 p.

Maisey JG AND CARvalho GP. 1995. First records of fossil sergestid decapods and fossil brachyuran crab larvae (Arthropoda, Crustacea), with remarks on some supposed palaemonid fossils, from the Santana Formation (AptianAlbian, NE Brazil). Am Mus Novit 3132: 1-17.

MARTILL DM. 2007. The age of the Cretaceous Santana Formation fossil Konservat Lagerstätte of north-east Brazil: a historical review and an appraisal of the biochronostratigraphic utility of its palaeobiota. Cretaceous Res 28: 895-920.

MARTILL DM AND WiLbY P. 1993. Stratigraphy. In: Martill DM (Ed), Fossils of the Santana and Crato Formations, Brazil. The Palaeontological Association, p. 20-50.

MARTINS-NETO RG AND MEZZALIRA S. 1991. Descrição de novos crustáceos (Caridea) da Formaçao Santana Cretáceo Inferior do Nordeste do Brazil. An Acad Bras Cienc 63: 155-160.

MARTINS-NETO RG. 2005. Estágio atual da paleoartropodologia Brasileira: hexápodes, miriápodes, crustáceos (Isopoda, Decapoda, Eucrustacea e Copepoda) e quelicerados. Arq Mus Nac (Rio J) 63: 471-494.

NEUMANN VH AND CABRERA L. 1999. Una nueva propuesta estratigráfica para la tectonosecuencia post-rifte de la cuenca de Araripe, nordeste de Brasil. V Simpósio do Cretáceo Brasileiro. DIAS-BRITO D et al. (Eds), Boletim de Resumos Expandidos, Serra Negra, Brazil, p. 279-285.

OLIVEIRA GR AND ROMANO PSR. 2007. Histórico dos achados de tartarugas fósseis do Brasil. Arq Mus Nac (Rio J) 65: 113-133. 
PÉREZ FARFAnTe I AND Kensley B. 1997. Penaeoid and sergestoid shrimps and prawns of the world. Keys and diagnoses for the families and genera. Mém Mus Natl Hist Nat 175: 1-233.

PonTE FC AND APPI CJ. 1990. Proposta de revisão da coluna litoestratigráfica da Bacia do Araripe. $36^{\circ}$ Congresso Brasileiro de Geologia. Natal, Brasil, p. 211-226.

PRICE LI. 1959. Sobre um crocodilídeo notosúquio do Cretácico brasileiro. Bol Div Geol Mineral 188: 1-55.

RIFF D, ROMANO PSR, OLIVEIRA GR AND AGUILERA OA. 2010. Neogene crocodile and turtle fauna in northern South America. In: HOORN C AND WESSELINGH EP (Eds), Amazonia, Landscape and Species Evolution. A Look into the Past. Blackwell Publishing, p. 259-280.

Romano PSR, Oliveira GR, AZEVEdo SAK, Kellner AWA AND CAMPOS DA. 2013. New information about the Pelomedusoides (Testudines: Pleurodira) from the Cretaceous of Brazil. In: BRINKMAN DB et al. (Eds), Morphology and Evolution of Turtles: Origin and Early Diversification. Dordrecht: Springer, p. 261-275.

SANTANA W, PINHEIRO AP, SILVA CMR AND SARAIVA AÁ. 2013. A new fossil caridean shrimp (Crustacea: Decapoda) from the Cretaceous (Albian) of the Romualdo Formation, Araripe Basin, northeastern Brazil. Zootaxa 3620: 293-300.

SARAiva AÁF, Hessel MH, GUERra NC AND FARA E. 2007. Concreções calcárias da Formação Santana, Bacia do Araripe: Uma proposta de classificação. Estudos Geológicos 17: 40-57.

SARAIVA AÁF, PRALON BGN AND GREgATI RA. 2009. Taxonomic remarks on Brazilian Cretaceous Decapoda from Araripe Basin, Brazil, and ecological inferences. Gaea 5: 70-74.

SCHRAM FR, FELDMANn RM AND COPELAND MJ. 1978. The late Devonian Palaeopalaemonidae and the earliest decapod crustaceans. J Paleontol 52: 1375-1387.

SCHRAM FR, SHEN Y, VONK R AND TAYLOR RS. 2000. The first fossil stenopodidean. Crustaceana 73: 235-242.

SMALL H. 1913. Geologia e suprimento d'agua subterrânea no Ceará e parte do Piauí. (25). Rio de Janeiro: Inspetoria de Obras Contra Secas.
TAVARES C AND MARTIN J. 2010. Suborder Dendrobranchiata Bate, 1888. In: SCHRAM FR et al. (Eds), Treatise on Zoology - Anatomy, Taxonomy, Biology — The Crustacea, Decapoda, Volume 9 Part A Eucarida: Euphausiacea, Amphionidacea, and Decapoda (partim), p. 99-164.

VALENÇA MM, NEUMANN VH AND MABESOONE JM. 2003. An overview on Callovian-Cenomanian intracratonic basins of northeast Brazil: Onshore stratigraphic record of the opening of the southern Atlantic. Geol Acta 1: 261-275.

VianA MS AND NEUMANN VHLIE. 2002. Membro Crato da Formação Santana, Chapada do Araripe, CE Riquíssimo registro de fauna e flora do Cretáceo. In: SCHOBBENHAUS C et al. (Eds), Sítios Geológicos e Paleontológicos do Brasil. DNPM/CPRM - Comissão Brasileira de Sítios Geológicos e Paleobiológicos (SIGEP), Brasília, p. 113-120.

VianA MSS AND Agostinho SM. 1995. Camarões do Membro Romualdo da Formação Santana (Cretáceo Inferior da Bacia do Araripe). XVI Simpósio de Geologia do Nordeste Sociedade Brasileira Geologia, Núcleo Nordeste (Ed) Boletim da Sociedade Brasileira de Geologia, Núcleo Nordeste, Recife, p. 239-243.

VILA-NoVA B AND SAYÃo JM. 2012. On wing disparity and morphological variation of the Santana Group pterosaurs. Hist Biol 24: 567-574.

VILA-NOVA BC, SARAIVA AAF, MOREIRA JKR AND SAYAO JM. 2011. Controlled excavations in the Romualdo Formation lagerstatte (Araripe basin, Brazil) and pterosaur diversity: Remarks based on new findings. Palaios 26: 173-179.

Wellnhofer P. 1985. Neue Pterosaurier aus der SantanaFormation (Apt) der Chapada do Araripe, Brasilien. Palaeontogr Abt A Palaeozool-Stratigr 187: 105-182.

Wellnhofer P. 1991. Weitere Pterosaurierfunde aus der Santana-Formation (Apt) der Chapada Do Araripe, Brasilien. Palaeontogr Abt A Palaeozool-Stratigr 215: 43-101. 